\title{
Beautiful and healthy! The woman in the pages of Alterosa magazine (1939-1945) DURING THE NeW State AND The Americanization process of Brazil
}

\author{
Gelka Barros
}

\begin{abstract}
The purpose of this paper is to analyze the discursive strategies present on illustrated magazine Alterosa. The aim is to understand the construction of Brazilian woman's social role in the period 1939-1945, a scenario that has redefined the bodily standard, conforming social behavior through moral values based on marital order. The methodology used combines text content analysis and photography. The theoretical input subsidizes reflections, based on Scott (1995), Perrot (2000), Maia (2001), Del Priori (2003) and Matos (2003), aggregating contextual specificity from the New State in Goellner (2008) and Carvalho (2011). To understand the circumstances of the Americanization process it sought dialogue with Tota (2000). From the analysis it has been concluded that speeches published in the magazine about women, by indicating traces of a body education, lined with the US mass culture nationalist and with the project of President Getúlio Vargas, which was known as New State (1937-1945) ans characterized by centralization of power, authoritarianism, populism, nationalism and anti-communism (Neto, 2013).
\end{abstract}

KEYWORDS

Social role; woman; body; New State; americanization

\begin{abstract}
Resumo
Este artigo tem por objetivo analisar as estratégias discursivas presentes na revista ilustrada Alterosa. O intuito é compreender a construção do papel social da mulher brasileira, no período de 1939 a 1945, cenário que redefiniu o padrão corporal, conformando condutas sociais, por meio de valores morais baseados na ordem conjugal. A metodologia utilizada combina análise de conteúdo de texto e fotografia. O aporte teórico subsidia as reflexões, embasando-se em Scott (1995), Perrot (2000), Maia (2001), Del Priori (2003) e Matos (2003), agregando a especificidade contextual do Estado Novo em Goellner (2008) e Carvalho (2011). Para o entendimento das circunstâncias do processo de americanização buscou-se diálogo com Tota (2000). Da análise conclui-se que os discursos publicados sobre a mulher na revista, indiciando traços de uma educação do corpo, se alinhavam à cultura de massa norte-americana e ao projeto nacionalista do presidente Getúlio Vargas, conhecido por Estado Novo (1937-1945) e caracterizado pela centralização do poder, autoritarismo, populismo, nacionalismo e anticomunismo (Neto, 2013).
\end{abstract}




\section{INTRODUCTION}

The Alterosa magazine was established in Belo Horizonte' in the year 1939 by journalist Olímpio de Miranda e Castro. With a monthly frequency since its launch, it had a branch in Rio de Janeiro, federal capital at that time. Periodical of varieties, of literary and news character, among its sections appeared mainly short stories and essays, interspersed with economic, political and social reports about Minas Gerais State, notes about the mineira ${ }^{2}$ society, humor, poetry, hobbies, entertainment such as radio and cinema, prescriptions about health, beauty and fashion, as well as advertising. In May 1943, it started to provide summary and the slogan "For the Family of Brazil". Alterosa reached its peak around 1950, when its circulation reached 60.000 copies circulating nationally.

In this article, all published editions, between 1939 and 1945, were systematically analyzed, available in the acquis of Municipal Newspaper Library Luiz de Bessa, in Belo Horizonte. The selected data are coming from advertising, advice column, reports, beauty column and fashion section, which make up part of the material intended to women in the magazine. The methodology used combines text content analysis and photography. The choice of this model seeks to capture the production processes of meanings present in social practices materialized in Alterosa, by means of communicational acts that, according to Barbosa (2009), characterize the correlation between communication and history, in so far as "history is always an interpretation done by who, from presentday, looks at the past. History is always narrative, something that has been narrated in the past and which we can now re-narrate" (Barbosa, 2009, p. 24). Because it deals with women and their social role, the theoretical input concentrates on gender studies, for this purpose, it is based on the conception that gender is "a constituent element of social relationships founded on differences perceived between the sexes, (...) is a first way of giving signification to relations of power" (Scott, 1995, p. 86). In this view, Scott (1995, p. 86) understands power through the concept of Foucault, "as dispersed constellations of unequal relations, discursively constituted in social 'force fields'”. Being gender the first manifestation of the relations of power, presented through discourse, it becomes essential to understand the way in which these relations were expressed in the construction of the feminine social role at that epoch. Therefore, in addition to identifying the representations of women in the magazine, it is necessary to understand the historical and social scenario that propitiated this ideal of femininity.

Approximately 40 years after its inauguration in 1897 , Belo Horizonte underwent a second modernization process due to its expansion beyond the urban perimeter defined in its construction plant. According to Chacham (1996), the period from 1935 to 1947, known as the "Skyscraper cycle", symbolized a new stage of progress in the city's history. In 1940, Juscelino Kubitschek ${ }^{3}$ was appointed mayor and remained in office until 1945.

\footnotetext{
' Belo Horizonte is the capital of Minas Gerais State and it was the first planned city in Brazil. The transfer scenario of the former capital Ouro Preto to the present one comprised the decay of the gold mining activity in the region and the change of the monarchical political regime to the Republic in 1889.

${ }^{2}$ Mineiro(a) is a term used to designate someone or something that originates in Minas Gerais State.

${ }^{3}$ Juscelino Kubitschek was president of Brazil from 1956 to 1961, when he built the new capital of the federation, Brasília.
} 
In the meantime, urban and social space continued to be transformed, intensified by the pavement of streets and avenues, formation of villages and neighborhoods, sanitation and earthmoving, construction of architectural complex of Pampulha, the Modern Art Exhibition, the creation of the Historical Museum of the City and the Institute of Fine Arts (Cedro, 2006). According to Cedro, Juscelino's ventures covered changes not only in the material ambit but in the cultural sphere, grounding the discourse of modernity and progress in coherence with the orientation of the New State, "seeking to include Belo Horizonte in the same modernization's context of the world's major cities" (Cedro, 2006, p. 85). It is worth reinforcing, according to Souza (2002), the impact of the increasing activity of the mass media in Belo Horizonte. According to the author, radio and, especially, the large American-style movie theaters contributed to the transformation of everyday subjectivities and acted on the habits and customs of the citizen from Belo Horizonte.

The images of the rapidly changing physical space of the city, the national radio in expansion as mass media and the growing Americanization of the country through Franklin Delano Roosevelt's "Good Neighbor Policy", whose main propagandistic element was the hollywoodian cinema, acted in this process. A scene composed by the insertion of photography in the urban culture of the capital, which, in addition to family albums and postcards, began to be displayed in profusion in the illustrated magazines, and by the Alterosa speech, which aimed to be the "great magazine of mineiros", based on one of the elements regrouped for the construction of the regional identity, the conjugal family.

\section{THE REGULATION OF THE FEMALE BODY}

Brazil, during the Vargas Era, specifically as of 1937, reports Tota (2000), was experiencing a process of Americanization aimed at achieving the alignment of the country with the US war effort. This propagandistic scenario was composed mainly by the mass media, like radio and cinema, that radiated the North American culture like reference of modernity. The press and printed propaganda were also instruments used for the "dissemination of Americanism principles" (Tota, 2000, p. 54). Although the author shows specific examples of US investment in the production of magazines On Guard (1941) and Reader's Digest (1942), the atmosphere that was created by the narrowing of relations between Brazil and the United States had repercussions on the Brazilian press, which started to publish North American content, in order to keep abreast of the current events in the world.

Amidst the turbulent context of World War II, the discursive strategy adopted by Alterosa valued the marital order. It was from the matrimonial bonds that emerged the roles defined for the white women, from middle and upper class: the mother, the wife and the housewife. Subjecting women to male authority was essential to the construction and maintenance of the family, which established the "natural" order of society. From the guardianship of the father to the guardianship of the husband, the women, under social 
judgment, had the function of ensuring the success of her marriage. According to Maia (2001), the conjugal family, legally constituted by the bourgeois marriage, was accentuated during the constitution of the Republic. Positivist political regime that perceived the family "as a strategic place to establish order and disseminate progress" (Maia, 2001, p. 5). Advertising and fashion, allied to the North American film industry, widely present in the pages of Alterosa, which obtained this content from the Pan-American Press news agency, were auxiliary tools in building the feminine social role. The persuasive character of the ads, whose objective is to convince its target audience, in this case, the women, realizes itself in the material plane for the acquisition of the product, and in the symbolic plane by the assimilation of an idea. The consumption of a product means to acquire the qualities it offers. Buitoni (2009, p. 29) points out that Brazilian female journalism, dating from the $19^{\text {th }}$ century, emerged "between literature and the said domestic arts and having as function the entertainment". Before this profile, the author emphasizes its secondary character linked to didactic utilitarianism. Except for a few periodicals that were concerned with the emancipation of women, the hegemonic women's press, over time, acted normatively for profit and keeping in mind not the woman, but the consumer (Buitoni, 2009). The regulation of the female body was intended to ensure the conjugal order and it was guided by two correlated elements: beauty and health.

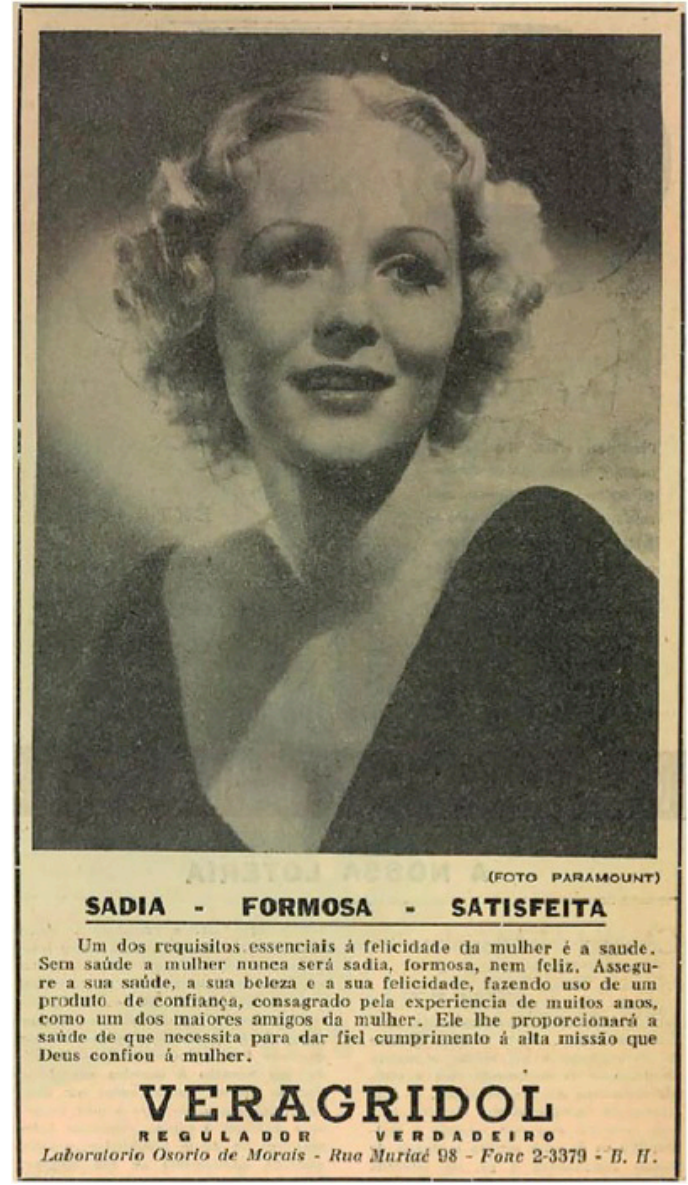

Figure 1: Ad for the regulator Veragridol Source: Veragridol, 1939, p. 21 
The regulator Veragridol assured to the woman physical conditions for fulfilling her social role: "without health a woman will never be healthy, beautiful, nor happy" (Veragridol, 1939, p. 21). Feminine beauty and happiness depended on their health, but these elements had no values or purpose in themselves, they were linked to conjugal happiness and to the "high mission that God entrusted to women" (Veragridol, 1939, p. 21). In this way, women's happiness depended on their ability to fulfill their destiny in society, to generate children. Reaffirmed by the insertion of religiosity, the women's natural condition needed to be regulated so they fulfilled their mission.

The photograph that makes up the black and white ad, as shown in Figure 1, depicts a beautiful white woman smiling, her countenance is tranquil. The smile, as an index of happiness, together with the artifice of the illumination of star's face, had enormous appeal in the social imaginary, then, in the construction of the feminine identity. Menezes asserts that advertising "exploits social values to build in the target audience the identifications necessary to ensure the effect of persuasion" (2012, p. 19). Thus, the model image of the star was configured as a convincing strategy for the acquisition of the product and the assimilation of the idea linked to it, inasmuch as the "manufactured" star by the cinema is "in herself, fashion figure while 'being-for-the-seduction"' (Lipovetsky, 1989, p. 214). The use of the image of an American movie star in the advertisement of a national product demonstrates how cinematic aesthetics was incorporated and reproduced on a large-scale in the magazine through model images as a way of educating the appearance, and, therefore, educating the women's body.

Film stars were transformed into "soldiers" in the fight against a common enemy. Tota states that "the 'patriotism' of cinema manufacturers in the fight against the Axis was also an opportunity to make fantastic profits. The European market was closed, remaining the Latin American" (2000, p. 66). The Hollywoodian cinema served to American foreign policy, both for the adhesion of the Brazilians to the North American ideological alignment, to suppress the Germanism in Brazil, and for the introjection of the cultural values, aiming at the opening of the market for material goods. The freedom propagated by the Americans did not only mean a political alignment to stop the Axis, but also intended the forging of modes of conduct for adhesion to the liberal values. It covered economic ends and turned culture into a marketing product. As Tota points out: "the process of Americanization through the cinema was effected by the market" (2000, p. 132).

The regulation of the female body was extended to the intimate care, directed to the containment of the proliferation of microorganisms together with the deodorization of the body. Ginorol, a product of Granado Laboratories, was indicated for the hygiene of the ladies. "Delicately perfumed" (Ginorol, 1939, p. 28) it had antiseptic, bactericidal and deodorizing action. The clean and perfumed body was part of the hygienic precepts that corresponded to the ideal of development of the nation, but hygiene was not limited simply to the regulation of the organism or to the correction of habits aimed at the cleanliness of the body, but also to the aesthetic correction. 
The soap Araxá linked the cleanliness and deodorization of the body to the feminine well-being. The properties of Araxá's ${ }^{4}$ salt and mud were responsible for the correction of skin imperfections, and promised beauty, health, and youth:

\begin{abstract}
a bath with Araxá soap provides unspeakable well-being and keeps the body permanently fragrant! Araxá soaps, made with the salt and mud of Araxá, universally known for its therapeutic virtues and in the treatment of the skin will extinguish all the defects that harm your skin, giving you health, youth and beauty! (Sabonete Araxá, 1939, p. 72)
\end{abstract}

The preoccupation with the healthy appearance was contoured by the air of youth, and the beauty, besides being able to be acquired, could be corrected. The conception of correction provided scope for the use of instruments for disciplining the female body so that it would fulfill its destiny in the ideal of nation-building.

The standardization of the women's body required the correction of habits and the introjection of the rules that governed the institution of marriage. For the management of marriage and the home, the women's behavior was directed to the control of her emotions, because that depended the education of her children and the representation of the social image of her husband. The way in which marital happiness was achieved was "marked by 'character', 'control', 'patience', and 'good humor'" (Norris, 1940, p. 136). The required self-control of the women was accompanied by restraint in financial expenses, gestures, and appearance. In this sense, any interference could result in the failure of marriage, always attributed to her. Accompanying Perrot's thought (2003, p. 13-22), it is through education that good habits are formed and good wives, mothers and housewives are produced. According to the author, it is a sociocultural construction of femininity, previously analyzed by Simone de Beauvoir, in the work, The Second Sex, 1949. Based on the difference between the sexes, she engenders elements such as restraint, discretion, the sweetness, the passivity, the submission, the modesty and the silence. Perrot distinguishes between education and instruction, the first being the formation of habits, and the latter access to knowledge. It is this conception of education that, in my view, helps to discuss the social role of women. In this sense, it can be said that the education of the women was given through corporal control, from the moment in which both scientific and political discourses acted directly on her body.

For the control of "female moods", Granado Laboratories offered Melissa's Water (Água de Melissa, 1941, p. 73), an exclusive drug for nervous palpitations, violent emotions, insomnia, and female syncopes. From the established relation between the uterus and the female physical and emotional state, Matos clarifies that "the medical discourse emphasized the connection between the uterus and the central nervous system, as well as the relations between the reproductive cycle and the female emotional states" (2003, p. 114). In this way, medicines directed to the women served both to regulate her organism and to control her emotional state, directing her behavior. A correction of feminine

\footnotetext{
${ }^{4}$ Araxá is a municipality to the south of Minas Gerais State, known for the medicinal waters of its thermal spas.
} 
nature for the sake of optimizing her body and spirit. According to Berger (1999), the representation of the feminine social role that has figured since Western Renaissance painting, and later propagated by the photographs of advertisements, deals with what women can and can not do. Female behavior is linked to the way a woman appears to other people. This means that caring for herself had a greater sense of caring for others, being "object of sight". Unlike the man who acts, the woman appears, and this way of appearing must be appreciated. In this way, the ideal of beauty was a capital that the women had for the scene in the social game, and it was through it that control over her body took place over time.

The use of the Lever soap guarantees the "perfect whiteness" of the skin. The "beautiful" Dorothy Lamour (Paramount) always used the product. "The moment the delicious foam of Lever caresses your skin, you will come into possession of the beauty secret of the stars!" (Sabonete Lever, 1945b, p. 119). The foam that caressed the skin was the vehicle that transmitted the beauty (cleaning) of the movie stars to the other women. The positive value given to the whiteness associated cleaning to white, which conveyed the idea of purification. In Gessy's slogan, these values were evident: " 50 years at the service of Eugenia and beauty!" (Sabonete Gessy, 1945, p. 59).The text of the ad highlighted, in the constitution of the product, "pure" elements and the "tonifying" and "rejuvenating" property of the skin. The message indicated that the hygienic precepts aimed at women had a greater meaning. In addition to cleanliness being essential for the gestation of healthy offspring, cleanliness was associated with a concept of whitening (and supposed strengthening) of the breed, being synonymous with purity and beauty.

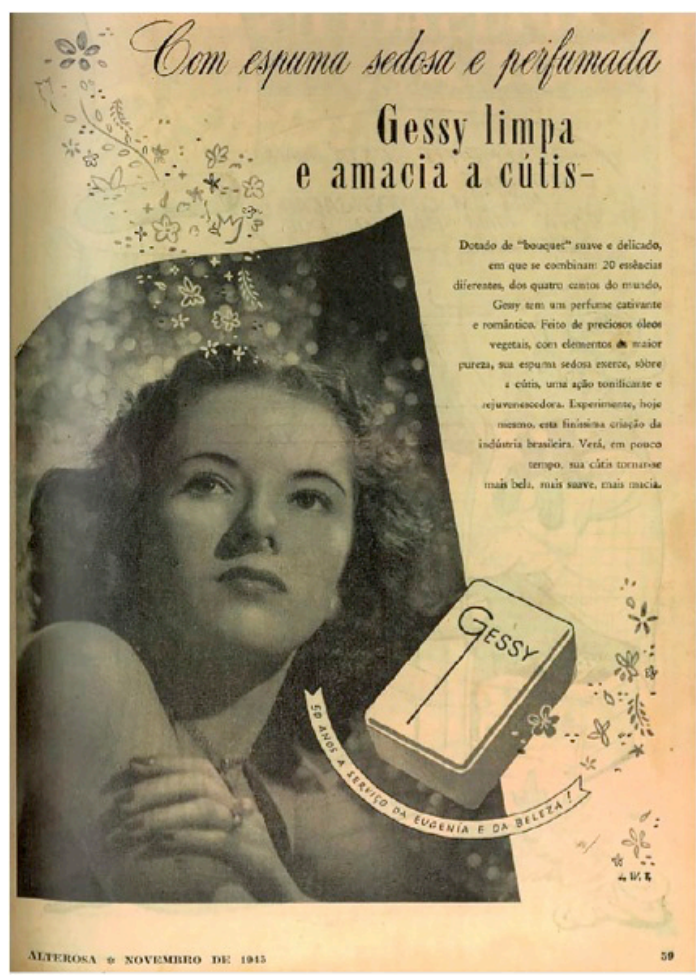

Figure 2: Ad for Gessy soap

Source: Sabonete Gessy, 1945, P. 59 
Figure 2 shows a white woman, her face expressing serenity and concentration. The photograph appears to have been held in the studio. Controlled light is essential to display a clean and healthy skin, beauty factors. Her stance highlights, still, the left hand, where a pearl ring on the ring finger suggests a wedding ring. The use of the hygiene product reinforces the idea of cleanliness, both for the women to contract marriage and to generate a healthy offspring. What is more, these white and clean women would be the ideal of femininity to be propagated for the nation's progress. For this, it was necessary to instill in women, besides hygienic habits, the imaginary representation of this ideal.

Therefore, the silences that surround the feminine weigh "first over the body, assimilated to the anonymous and impersonal function of reproduction" (Perrot, 2003, p. 13). From this view, it is understood that the social role of women was determined biologically, and for this reason, was naturalized. Thus, care for herself extended to the care of the other, in her family nucleus, in the private sphere, place of reproduction, by the sexual division of labor. However, from the interweaving of these "cares", in the face of the conjuncture of World War II, the possibility of her action in the public sphere arose.

\section{THE CIVIC WOMAN AND THE PUBLIC SPACE}

The woman's entry into the labor market was marked by the discourses that feared it as a threat to the family and desired her return home, since the public sphere was male domain, place of production. During this period, the Civil Code of 1916 was still in force, which, according to Maluf and Mott (2004), perpetuated female subordination to men by subjecting her right to work to her husband's authorization or, in some cases, to the legal court. At the end of 1942 and during 1943, several newspaper reports on women and their participation in the world conflict brought to light the debate on the female social role in public space. During this time Alterosa presented the "achievements of the women", the reinforcement of her central role as manager of the family was present and the discursive strategies were ambiguous, considering that the conservative character was hegemonic in the magazine.

To a large extent, female work outside the family was accepted when it was linked to the need to obtain material resources. The difference between the jobs that could be exercised by the women was associated with their social condition. The women without financial resources always worked, and middle and upper class women exercised jobs related to the idea of caring for others, such as teachers and nurses, these occupations were considered legitimate by the naturalization of the "feminine gift of donation." In this sense, social assistance, seen as a feminine occupation, was strengthened during the Brazilian war effort. Brazil's entry into World War II, in August 1942, was accompanied by some governmental acts, among them the creation of the Brazilian Legion of Assistance (Simili, 2006). Directed by First Lady Darci Vargas, the care institution was intended to support the families of Brazilian soldiers summoned for the country's war effort.

One of the articles published by the journal on women's participation in the war effort did not clarify exactly how these activities were carried out. Its focus was on 
presenting the development of the "civic consciousness of mineira woman", along with an "energetic wave of patriotism" that involved the whole society. This atmosphere of civility was reinforced by the use of uniforms that identified who worked in the Brazilian Legion of Assistance or the Red Cross. The uniform as a visual code gained the purpose of propagating the patriotic values and discipline that guided the female contribution to the conflict, serving as a symbol for the civic woman who had the maternal function:

the Samaritans of Liberty put aside their vanities and understood the reasons why the maximum renunciation is necessary. To mothers were told to keep their tears because their children are blessed by the Homeland. The brides are seeing their loved ones leaving for the barracks and if they do not return they will remain forever as brides of heroes. (A contribuição da mulher mineira ao esforço de guerra do Brasil, 1943, p. 73)

Voluntary work, seen as much needed at the time, required sacrifices for the love of the Homeland. The renunciation and the act of taking care of the other were part of the women's role, so this work was destined for her. The Homeland, as a divine entity, would bless and glorify all who fulfilled their roles in its defense. In this way, the female volunteer framework contributed both to social assistance and to Brazilian political propaganda during the war effort.

Similar arguments were published in another article (Pinto, 1943, p. 66) about the National Aviation Campaign, in which the mineira woman supported the country as an "air nurse" or "passive anti-air defense". The use of the distinctive of the Belly Fraternity or the Brazilian Air Force reinforced patriotic values and the role of women in caring for each other.

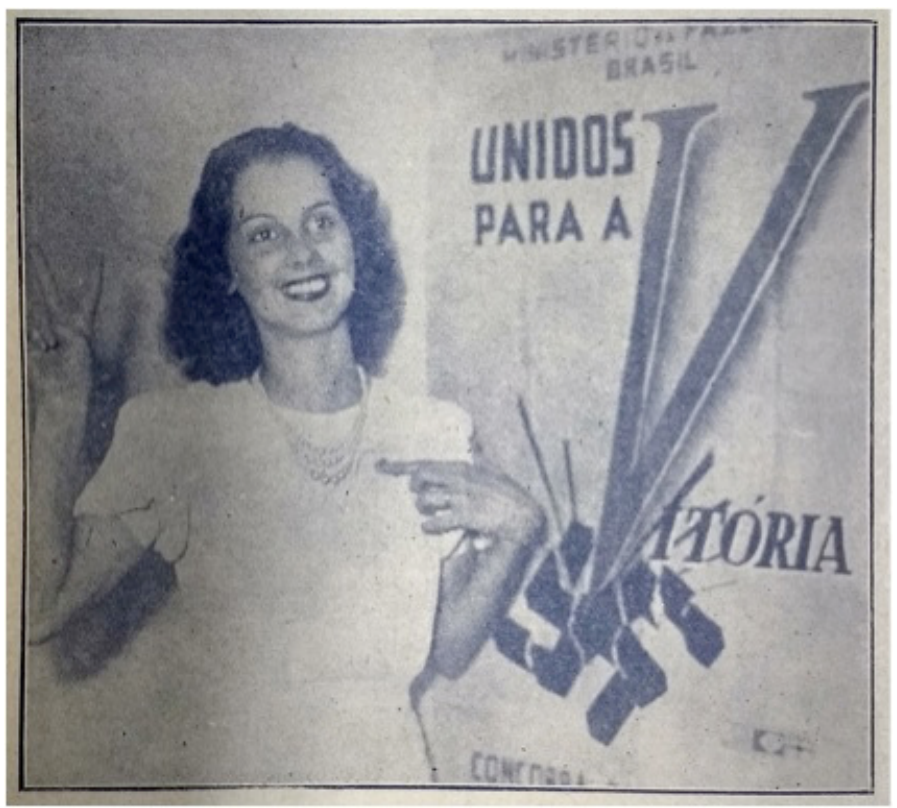

Figure 3: The support of mineira woman to the National Aviation Campaign Source: Pinto, 1943, p. 103 
Figure 3 shows Ms. Hortência Mendes de Oliveira and Freitas posing next to a poster that shows the expression "united for victory", in uppercase. The letter V (of Victory) in body greater than the others focuses on the Nazi swastika. She smiles, with her right hand she makes the symbol of peace, and with the left indicates the badge of the Belly Fraternity. There is no lighting artifice similar to the cinematic aesthetics, and the one who appears in the image is not a movie star, attesting the participation of ordinary people in the war effort, just as other ladies from mineira society, who had pilot's license, were exhibited (Figure 4).

Naming the ladies and displaying their images in the photographs points to Alterosa's strategy, in line with the nationalism of the Vargas government, to produce female membership. In order to bring volunteers to the cause, the "bravery" of the girls who took the piloting course was used for motivation, as shown in Figure 4: Misses Maria Helena Salvo de Souza and Eni de Andrade, from left to right, dressed for this purpose. Bravery as a masculine characteristic was attributed to the women in order to elevate her to a condition of participation in the conflict. Although they were not to act directly in the war, this sense of patriotism was fed to direct the women to the desired role, and thus the figure of the "air nurse" was created.

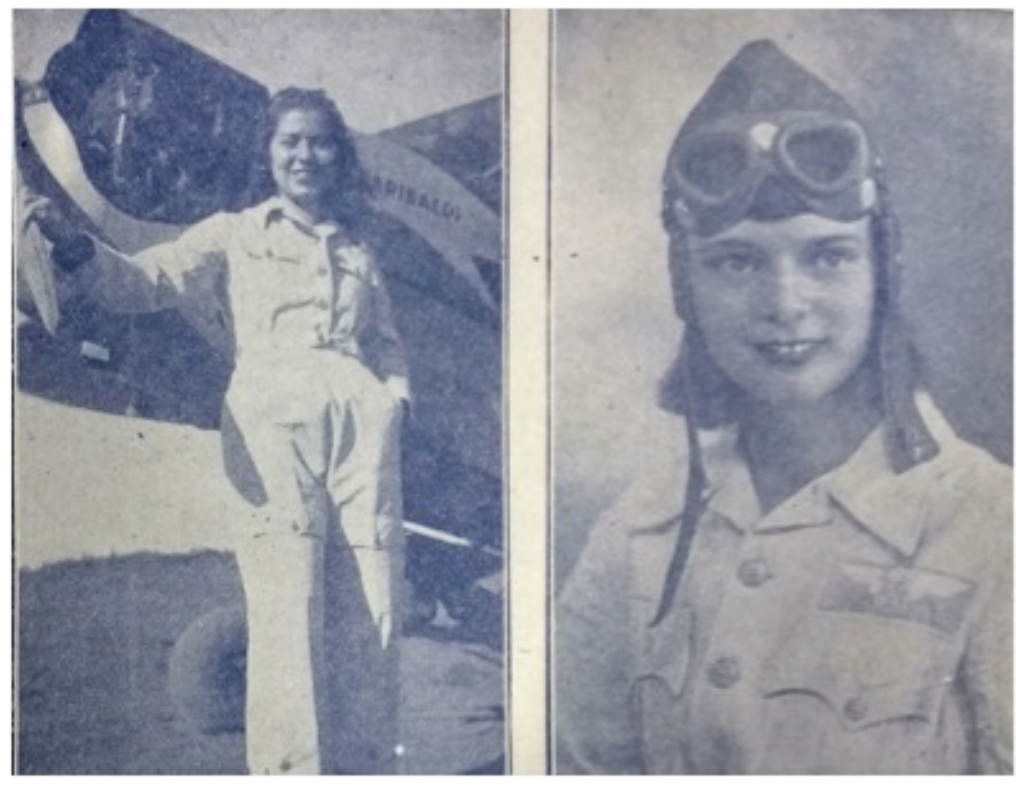

Figure 4: The support of mineira woman to the National Aviation Campaign Source: Pinto, 1943, p. 103

The text of the article exhibited a feminine speech as representative of the women, without crediting the authorship:

We can not fight like men, taking an active part in the space combats (...).

They think the mission is too heavy for us, they think it's too much of a sacrifice for women to police the air (...). Let us be, then, the air nurses.

(Pinto, 1943, p. 103) 
Clearly what was expected of the women was caring for the other, so her "fragile and passive" nature (despite her bravery) was used as an argument to restrain her direct action in the conflict. According to Simili (2006), the passive defense project formation aimed to prepare women to take care of the material and symbolic goods of the country. In this sense, care with the family has been extended to the public space, to the nation.

At that moment, the debate about the increasing entry of mineira women to higher education (A mulher mineira invade a Universidade, 1943, p. 129) and the labor market (Montanhez, 1944, p. 78) has made with which the magazine published other material on the performance of women in public space. One of the factors of this change was the cultural exchange with the Americans. Not that the American woman were emancipated, on the contrary, her expected social role was similar to that of the Brazilian, but her performance during the war effort was active, and this may have signaled the difference. While North Americans acted directly to fill the gap in various economic sectors, due to the direct involvement of their country in the conflict, which involved the qualification and education of these women, middle and upper class Brazilians acted in charity and commerce. Even in the face of this difference, there was some change in the view on female performance in the public sphere in Brazil, since the American culture was considered modern.

In one of the reports about the war, in the face of some victories of the Allies, it wondered what the world would be like after the end of the conflict. The announcement that this was the women's moment showed that somehow the view on women was changed during the conflict. The text affirmed that the reconstruction of the countries would involve the presence of all, without distinction of class, race, age or gender:

this will also be the time for women. They will be free from a great number of prejudices and they will stand next to their comrades, fighting side by side, speaking the same productive and secure language and occupying the same places, because they will represent the same human force as men.

(Novos horizontes para a mulher, 1943, p. 18)

The economic gap opened by the war has made it easier for women to act in society so that they were able to demonstrate their ability to work outside the domestic sphere. Probably, this was the reason for the prediction of their equivalence in the productive and human force, although evidencing the permanence of sexual distinctives, since, at another time, the text referred to the women as "weak sex". Moreover, the discourse indicated that, until then, there was inequality not only between the genders, but between the classes and the races. The report showed as models the North American, spectrography techniques at Chrysler Corporation, United Air Lines flight instructors and engineers at $\mathrm{Cia}$. Monsanto Chemical, stating that the way to take advantage of this opportunity was to study, "the watchword that was dictated, not by chiefs, but by the moment, by the evolution of the world" (Novos horizontes para a mulher, 1943, p. 19).

Women's participation in public space stressed their social role in the private environment. Concern about the labor market dispute was seen as a hindrance to the 
formation of new family structures based on the conjugal model. In this sense, the permanent reinforcement of the social roles of caregiver (women) and provider (men) was justified, since the family was considered as a stable social model, and the flexibilization of these roles risked the construction of the values of the nation.

\section{THE BEAUTIFUL AND VIGOROUS BODY FOR THE IMPROVEMENT OF THE RACE}

Valuing healthy habits meant civilizing the nation. The body as the vector of modern conditioning required education to correspond to this way of life, as well as to express and disseminate its intrinsic values. In Minas Gerais, in the 1930s and 1940s, it was delegated to medical knowledge "the power and duty to sanitize the social body through hygienic education and Eugenia", according to Carvalho (2011, p. 4). "The intention to strengthen the female body through the practice of physical activities in order to prepare it for the conduct of a healthy motherhood", reports Goellner $(2008$, p. 12), occurred in several countries such as Argentina, Germany, United States, United Kingdom, France, Italy, Spain and Portugal. Thus, the performance of public power in the formation of Brazilian women found harmony with the North American cultural model that, in the midst of the process of Americanization of the country, was propagated primarily by the Hollywood film industry.

The state public power encouraged the practice of physical culture through a set of measures; the most emblematic, among them, was the creation of Minas Tennis Club. According to Rodrigues et al. (2014), the club, created in 1935 and inaugurated in 1937, was built by Belo Horizonte City Hall and leased by a group of the city's political and economic elite. The news published in the magazine about the club featured the volleyball and tennis courts, exercise equipment, and the swimming pool, especially the trampoline, suggesting the vigor with which the State exercised the actions aimed at physical improvement. Its activities, supported by the government of Minas Gerais, were "a great work of eugenics and civilization" one of the most vast achievements of mineira energy. According to Goellner (2008), physical education and sports were the pillars of the Vargas project of aggrandizing the homeland, aimed at strengthening the population, racial cleansing and building a sense of national identity. The efforts undertaken have created conditions to educate, strengthen and improve the female body of the white women as an instrument of physical and racial regeneration of the population. In this way, women's sports was institutionalized as a preparation for healthy motherhood, while at the same time making it possible for women to enter the public sphere.

The taste for physical activity developed as a modern practice of body cultivation, providing a form of fun in Belo Horizonte. Although the women integrated the change of habits in the capital, there was the concern with the maintenance of its femininity. The mineira "also participated in this movement, without diminishing their predicates of grace, austerity, virtues. To their moral robustness, the qualities of physical resistance, of elegance and of plastic were allied" (Umas das mais vastas realizações da energia mineira!, 1939, p. 51). The fact of reserving a portion of the article to clarify that the 
mineira woman had not lost her attributes indicated that there was some resistance on the part of society regarding the performance of female physical practice. Sports, which gave women a certain emancipation in the public sphere, retained conditions related to their social function. Body exercise should strengthen the female body without altering its image as a motherly, beautiful and feminine women, "without depriving them of the harmony of forms, the beauty and the grace" (Goellner, 2008, p. 14).

The image of the beauty and elegance of the women was reproduced by fashion, through the introduction of seasonal novelties, which indicated its use in the set of senses that guided the mentality of the time. The "beautiful" sports models were used by the stars "on hot summer days, (...) in the swimming pools, tennis courts and country walks" (O calor convida as piscinas, 1939, p. 68). Unlike the other images previously presented, the fashion section of the magazine generally featured a composition with several photographs showing the full-body stars in order to display the models of dress. Figure 5 presents three different models, in scenes that try to reproduce the stars in the open air, but the use of scenographic features is perceptible. The young women did not wear specific suits for the mentioned sports, and their poses did not refer to sports practice, indicating that the interest of the article was to propagate the image of beautiful and healthy bodies, conquered through the practice of physical exercises. A new body appearance, a new way of dressing, a new life style. It is even noticed that one of the stars was wearing "high heels", an element of fashion fetish, a sign of seduction and elegance. The illustration of the sun smiling and radiating its heat over the bodies, signaling health and vitality, invited to sports in the summer.

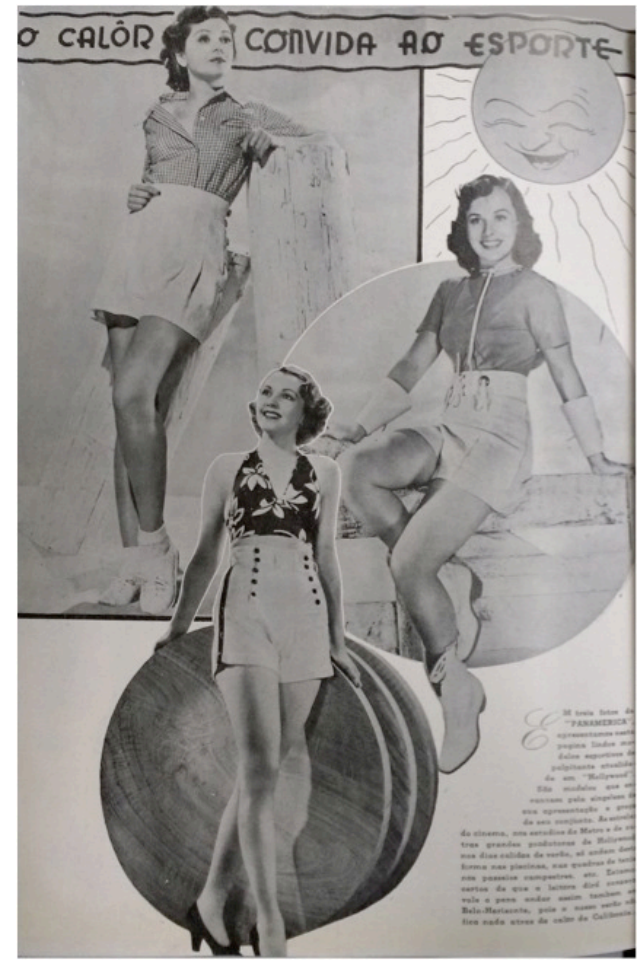

Figure 5: The heat invites to sports

Source: O calor convida ao esporte, 1939, p. 102 
Fashion, under the impact of sports, has transformed the feminine appearance. According to Lipovetsky, roughly, from the 1920s, sportswear began to be used for outdoor walks in the city, and not just for sports. Gradually, these robes were stripping the bodies, especially the female. The natural body shows itself without the excessive tricks of the previous garment, which implied changes in the lines of the costumes, creating a new aesthetic ideal of femininity, the slender, slim, modern women who practiced sports (Lipovetsky, 1989, pp. 76-77).

The text of the article went on "we are sure that the reader will say to us: it is worthwhile to walk in this way in Belo Horizonte too, because our summer is not far from the heat of California..." (O calor convida ao esporte, 1939, p. 102). The affirmation of parity between the city of Belo Horizonte and the State of California suggested the confluence of interests in the adoption of North American cultural model, in the attempt of composition of the mineira women. Buitoni points out that photography next to the text has become a major attraction in magazines, especially women's magazines, since "the image becomes text, with series of photos constructing true 'visual phrases'; and the text becomes an image when it comes to figures of style that make us visualize the person or the scene, or suggest emotions and feelings" (1986, p. 19). Campos (2008) reports that photography was incorporated into daily life in Belo Horizonte around 1940, after the professionalization of the photography field in the city. According to the author, photography is an artifact that shapes itself as a product and producer of social habits. That said, photographic culture can be understood beyond social practice, being a way of representing the world and society, characteristic of the principle of modern visibility, seeing and being seen. In this context, Alterosa, through its discursive strategy of identity, used photography profusely as a disseminator of values in the social body of the city, together with the ideals of the New State and the images of the North American industrialized culture, which served for the diffusion of the example of women required for the ideal of nation.

The aesthetic standard now imposed was not fully accepted. Patricia Lindsay5, a beauty columnist, responding to a group of young readers who criticized the beauty of the tall, slender female figure, claimed that the new generation girl seemed taller than her predecessors. The accompanying photograph showed a slender, slim white woman with the following caption: true beauty is tall and slim. The defense of this aesthetic model used the argument of truth, denying to other aesthetics the possibility of a real beauty, treating them as misleading. According to the text, "in the female tendency for meat shortages, it is not only intended to look fashionable, but also to improve health" (Lindsay, 1941, p. 10). The goal was not just to match a fashion-oriented model, that is, to look lean. It was necessary to make the body sound. The dynamism of the new times demanded agile bodies and fat was the great villain of efficiency, associated with the aging and ugliness of the body. In this way, physical practice and diet became mandatory

\footnotetext{
${ }_{5}^{5}$ Patricia Lindsay reported her advice to her US readers. Although the American content portrayed the reality of that country, it did not seem incompatible with the Brazilian, in view of the universal Western discourse on the representation of the feminine based on biological determinism, whose roots go back to Greek philosophy. Representations adopted by the great monotheistic religions of the West that have been reinforced over time by politics and medicine (Perrot, 2003, pp. 20-21).
} 
behaviors for a healthy life, whose greater expression was slenderness. The columnist mentions that the critical girls of this model of beauty retaliated the thin, referring to them as looking like their brothers. A misogynist behavior circumscribed to the female universe, which related the beauty model to masculinity, disqualifying it, and resembling the discourses that saw the loss of femininity of the female sportswomen.

A section of photos in the dependencies of the "Minas Tennis Club" defined what these woman were like. Alterosa presented the image of the "beautiful" star from R.K. Radio, Frances Nell, to demarcate which type of woman was intended to form and to demonstrate the pattern to be followed.

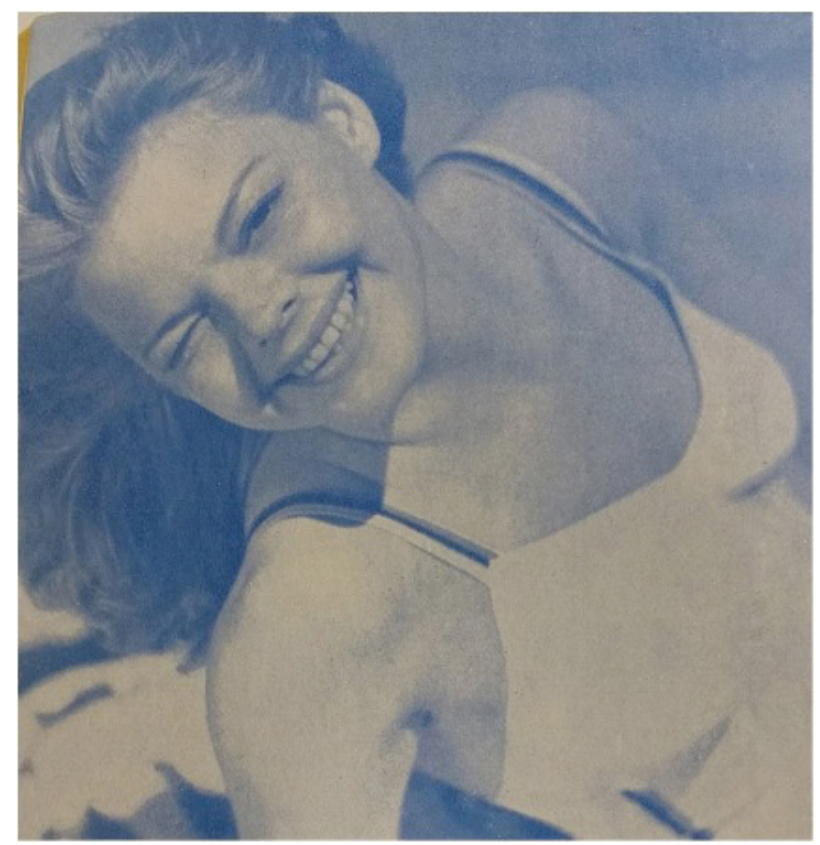

Figure 6: Frances Nell, Frances Nell, R.K.O Radio star Source: Minas Tenis Club, 1941, p. 46

Part of the photographic legend read "in the photograph above, it gives us an idea of the kind of woman that is forming in Minas Gerais. Beautiful, healthy and strong" (Minas Tenis Club, 1941, p. 46). Figure 6 shows a beautiful, white, slender woman, smiling in the sun. These were the ingredients for a species preparation. The star is lying in the sun, dressed in a swimsuit, her body rests on her right arm, and her right eye is closed. The photograph suggests a flagrant. When approached, the star tilts her body and looks up, trying to see who was approaching her. From this movement her corporal support and the closing of one of the eyes derive. However, she does not cover her eyes with her hands because her face was the goal of the realization of the image. The idea was to indicate that there were other women with this standard of beauty circulating in the sports associations of Belo Horizonte, and this seemed to be enough to attest to the "success" of the project of improvement of the race and to encourage the adhesion of the young mineira women. Menezes (2012, p. 23) affirms that the image of women, especially in advertising, passes through the appropriation of their body, which is defined by values, 
demands and interests of the hegemonic class. Thus, it is the body which sustains sociocultural values and legitimizes the projects of political and economic power.

The defense of the physical practice of women was based on the instrumentalisation of their body for the improvement of the Brazilian people "let us make from Sports, with the magnificence of its undeniable virtues, an integral part of the feminine education of the daughters of the Century, for greater glory of the women, to the greater splendor of the race" (Esporte como fator de beleza, 1942, p. 46). In her desire for beauty, the women were instigated to correspond to the ideal of beauty that embodied vigor. In the words of Alterosa, the "type of Venus" that dominated "the universal feeling of beauty" (Guiomar Marlane e a arte de ser bela, 1943, p. 38), at that time, was the Brazilian singer ${ }^{6}$ Guiomar Marlane. "Today's women, to be beautiful, must first of all be strong. Sporty, slender, with quick and easy movements, the modern women dance, swim, do gymnastics and work" (Guiomar Marlane e a arte de ser bela, 1943, p. 38). The aesthetic norm has transformed the female body, formerly considered fragile, into a strong body, synonymous with beauty. In this way, the modern women moved outdoors (outside the domestic sphere), exercised a profession and exercised her body. This energetically propagated aesthetic and ideological pattern built the ideal women who sought "to achieve integral beauty in the dynamism of the conception of modern life, creating the mentality of spiritual rejuvenation in the salutary practice of outdoor sports" (Silhuetas tentadoras, 1945, p. 76). The conception of integral beauty, at that time, was elaborated to accompany the modern rhythm, in which body and mind rejuvenated by sports practice. The photographs of the "beautiful, elegant, and agile" bodies of movie stars in modern clothing were icons of perfection attesting to the path to follow.

This system of images (visual and verbal) shared by fashion and publicity, in a didactic way, transmitted between the lines the values of the conjugal model, the belief in science and technique, the consecration of hygiene and health as factors of beauty, and more, it propagated that Brazil was civilized by its approximation with the North American culture, presented and seen as a model of progress.

\section{FinAL CONSIDERATIONS}

Within the limits of this text it was not possible to address all the aspects involved in the "new Brazilian women" training project. For that reason, some indicators of the national project that had the women as the main element for the improvement of the Brazilian people were presented and analyzed, demarcating how this process was propagated by the magazine Alterosa, because it understood that the journal intended to affirm the regional identity, inside the nationalist politics of the New State, through the value of identity - the conjugal family.

The scenario compound of closer relations between Brazil and the United States, due to the confluence of interests between countries and the consequent ideological

\footnotetext{
${ }^{6}$ National radio was presented in the magazine in the same aesthetic form of American mass culture. In this way, the queens of the radio were equated with movie stars.
} 
alignment on the social role of women, created a conducive environment to legitimization of an ideal of femininity, which symbol used for persuasion was the star of Hollywoodian cinema. The discursive strategies present in the magazine led, stimulated and induced the deodorization, correction and strengthening of the body, the control of humor, the normalization of behavior from the white women, from middle and upper class, affirming their place of destination in the private sphere. What did not seem to have been foreseen in the "new women" project was their growing performance in the public sphere, due to work and sports, which has strained its role in the domestic sphere. The permanent reinforcement of sexual distinctives indicated the preoccupation with the maintenance of the conjugal order.

The notion of health managed by the coercion of the pattern of beauty established herein governed behaviors aimed at healthy motherhood, fruit of the perfection of the race. This was the direction that guided this hegemonic system of representation, in which photography, as an integral part of the body education process, was essential in the construction of the "new women" image, due to its credibility as a document of a certain reality. This was the modern women propagated by Alterosa magazine: Beautiful and healthy! /

\section{BibLIOGRAPHIC REFERENCES}

A contribuição da mulher mineira ao esforço de guerra do Brasil (1943, March). Alterosa, 5(35), p. 73.

A mulher mineira invade a Universidade (1943, November). Alterosa, 5(43), p. 129.

Água de Melissa (1941, December). Alterosa, 3(21), p. 73.

Barbosa, M. C. (2009). Comunicação e história: presente e passado em atos narrativos. Comunicação, mídia e consumo, 16, 11-27. Retrieved from http://revistacmc.espm.br/index.php/revistacmc/article/ view/154/155.

Berger, J. (1999). Modos de Ver. Rio de Janeiro: Rocco.

Buitoni, D. H. S. (1986). Imprensa feminina. São Paulo: Ed. Ática.

Buitoni, D. H. S. (2009). Mulher de papel: a representação da mulher pela imprensa feminina brasileira. São Paulo: Summus.

Campos, L. C. M. (2008). “Instantes como estes serão seus para sempre”: práticas e representações fotográficas em Belo Horizonte (1894-1939). Master Dissertation, Universidade Federal de Minas Gerais, Belo Horizonte, Brazil.

Carvalho, K. A. (2011). Em busca do tipo ideal: a perspectiva de reforma social dos medicos sanitaristas mineiros (1930-1940). Revista Ágora, 12, 1-21.

Cedro, M. (2006). A administração municipal do prefeito Juscelino Kubitschek: estética e planejamento da cidade de Belo Horizonte na década de 1940. Oculum ensaios, 5, 81-91. Retrieved from http://periodicos. puc-campinas.edu.br/seer/index.php/oculum/article/view/390 
Chacham, V. (1996). A memória urbana entre o panorama e as ruínas: a rua da Bahia e o Bar do Ponto na Belo Horizonte dos anos 30 e 40. P.183-230. In E. F. Dutra (Ed.), BH: horizontes históricos (pp. 183-230). Belo Horizonte: C/ Arte.

Del Priori, M. (2000). Corpo a corpo com a mulher: pequena história das transformações do corpo feminino no Brasil. São Paulo: Senac.

Esporte como fator de beleza (1942, September). Alterosa, 4(29), p. 46.

Ginorol (1939, December). Alterosa, 1(5), p. 28.

Goellner, S. V. (2008). As mulheres fortes são aquelas que fazem uma raça forte: esporte, eugenia e nacionalismo no Brasil no início do século XX. Recorde, 1. Retrieved from https://revistas.ufrj.br/index. php/Recorde/article/view/790

Guiomar Marlane e a arte de ser bela (1943, February). Alterosa, 5(34), p. 38.

Lindsay, P. (1941, April). A moça delgada nada tem a ver com a moça magra. Alterosa, 3 (13), p. 10.

Lipovetsky, G. (1989). O império do efêmero: a moda e seu destino nas sociedades modernas. São Paulo: Companhia das Letras.

Maia, C. J. (2011). Genealogia da solteirona no Brasil. Communication presented in XXVI Simpósio Nacional de História, São Paulo.

Maluf, M. \& Mott, L. (2004). Recônditos do mundo feminino. In N. Sevcenko (Ed.), História da vida privada no Brasil (pp. 367-421). São Paulo: Companhia das Letras.

Matos, M. I. S. (2003). Delineando corpos: as representações do feminino e do masculino no discurso médico. In M. I. S. Matos \& R. Soihet (Eds.), O corpo feminino em debate (pp. 107-127). São Paulo: Unesp.

Menezes, D. (2012). Construções da imagem feminina na propaganda: para além do efeito persuasivo. Comunicação e Sociedade, 21, 19-38. Retrieved from http://revistacomsoc.pt/index.php/comsoc/article/ view/697

Minas Tenis Club (1941, April). Alterosa, 3(13), p. 46.

Montanhez, R. (1944, May). As mulheres vencem na luta pela vida. Alterosa, 6 (49), p.78.

Neto, L. (2013). Getúlio: Do Governo Provisório à ditadura do Estado Novo (1930-1945). São Paulo: Companhia das Letras.

Norris, K. (1940, September). Ha mulheres que não encontrariam felicidade em nenhum casamento. Alterosa, 2(9), p. 136.

Novos horizontes para a mulher (1943, September). Alterosa, 5(41), pp. 18-19.

O calor convida ao esporte (1939, December). Alterosa, 1(5), p. 102.

Perrot, M. (2003). Os silêncios do corpo da mulher. In M. I. S. Matos \& R. Soihet (Eds.), O corpo feminino em debate (pp. 13-27). São Paulo: Unesp.

Pinto, N. A. (1943, April). A mulher mineira apoia a Campanha Nacional de Aviação. Alterosa, 5(36), p. 66-103. 
Rodrigues, M. A. A.; Isayama, H. F.; Costa, L. C. L. R.; Peres, F. A. S.; Oliveira, R. M.; Viana, J. A.; Silveira, A. C. C.; Silva, M. A. F.; Lopes, T. B.; Xavier, J. L.; Lana, V. L. \& Saad, J. (2014). Um olhar sobre a trajetória das políticas públicas de esporte em Minas Gerais: 1927 a 2006. In M. A. A. Rodrigues \& H. Isayama (Eds.), Mapeando as primeiras ações de politicas publicas de esporte em Minas Gerais (1927-1946) (pp. 29-46).

Contagem: MJR.

Sabonete Araxá (1939, August). Alterosa, 1(1), p. 72.

Sabonete Gessy (1945, November). Alterosa, 7(67), p. 59.

Sabonete Lever (1945, September). Alterosa, 7(65), p. 119.

Scott, J. W. (1995). Gênero: uma categoria útil de análise histórica. Educação a Realidade, 2, 71-99.

Silhuetas tentadoras (1945, September). Alterosa, 7(65), p. 76.

Simili, I. G. (2006). O que virou moda? As voluntárias da Legião Brasileira de Assistência no Jornal Correio da Manhã. . Communication presented in XVIII Encontro Regional de História, São Paulo.

Souza, E. M. (2002). Olhares do cidadão. In T. V. C. Pimentel (Ed.). Juscelino Prefeito 1940-1945 (pp. 47-57). Belo Horizonte: Rona Editora.

Tota, A. P. (2000). O imperialismo sedutor: a americanização do Brasil na época da Segunda Guerra. São Paulo: Companhia das Letras.

Umas das mais vastas realizações da energia mineira! (1939, August). Alterosa, 1(1), p. 51.

\section{BIOGRAPHICAL NOTE}

Gelka Barros is a PhD student in Leisure Studies (Culture and Education) Federal University of Minas Gerais (UFMG). Master in Leisure Studies - UFMG (2013). Graduation in Visual Arts - Guignard School / UEMG (2010) and Social Communication (Advertisement and Propaganda) - PUC-MG (1998). Since 2006, research the interfaces between body and image.

E-mail: gelkabarros@yahoo.com.br

Rua Horizonte, 211 - Paraíso - Belo Horizonte - MG / Brasil - CEP: 30.270-270

* Submitted: 31-07-2017

* Accepted: 07-11-2017 